\title{
FAKTOR-FAKTOR YANG MEMPENGARUHI MOTIVASI KERJA DI BCA KCU PANGERAN JAYAKARTA
}

\author{
SYAFAATUL HIDAYATI ${ }^{1)}$, RAJIB RIPANDI ${ }^{2)}$ \\ ${ }^{1}$ Dosen Pendidikan Ekonomi Universitas Pamulang \\ ${ }^{2}$ Mahasiswa Pendidikan Ekonomi Universitas Pamulang \\ dosen00861@unpam.ac.id.
}

\begin{abstract}
ABSTRAK
Tujuan penelitian ini adalah untuk mengetahui bagaimana pengaruh upah terhadap motivasi kerja di BCA KCU Pangeran Jayakarta. Penelitian ini menggunakan pendekatan kualitatif. Teknik pengumpulan data yang peneliti gunakan yaitu observasi partisipan, wawancara mendalam, dokumentasi dan angket. Berdasarkan hasil penelitian terhadap faktor-faktor yang mempengaruhi motivasi kerja di BCA KCU Pangeran Jayakarta menunjukkan bahwa upah merupakan salah satu faktor yang sangat berpengaruh dalam motivasi kerja karyawan. Pada saat ini upah yang diterima oleh karyawan sudah cukup namun ada beberapa karyawan yang masih merasa bahwa upah yang mereka terima masih kurang dan mereka menginginkan agar menendapatkan upah yang lebih tinggi. Disamping itu motivasi karyawan saat ini sudah tidak mengalami kendala. Untuk itu, maka disarankan bagi karyawan diharapkan dengan adanya penelitian ini dijadikan sebagai pandangan dan pengetahuan keilmuan bagi masyarakat khususnya para buruh/pekerja agar mengetahui begitu besar peran buruh/pekerja dalam perekonomian. Bagi KCU BCA Pangeran Jayakarta, supaya dapat meningkatkan motivasi kerja yang baik terhadap karyawan dengan meningkatnya motivasi tersebut dapat membangun perusahaan menjadi lebih baik. Bagi peneliti selanjutnya, untuk diadakan penelitian lanjutan dengan cakupan yang lebih luas tentang motivasi kerja.
\end{abstract}

Kata Kunci: Motivasi Kerja, Upah 


\section{PENDAHULUAN}

Globalisasi telah muncul sebagai fenomena yang berdampak cukup besar bagi industri-industri di Indonesia baik itu industri manufaktur, perdagangan, maupun jasa. Kondisi ini menuntut industri untuk senantiasa melakukan berbagai inovasi untuk dapat bersaing dan memiliki keunggulan dalam hal kualitas dan kuantitas produk, pelayanan, maupun harga produk untuk dapat bersaing dan mempertahankan keunggulan perlu diakui bahwa peran pekerja sangat penting sebagai penggerak aktivitas industri, sehingga perlu mendapat perhatian tersendiri karena merekalah yang meluangkan waktu, pikiran dan tenaga. Disamping itu mereka memiliki perasaan, kebutuhan dan harapan-harapan yang dapat mempengaruhi kinerja pekerja, dedikasi, dan loyalitas, serta kecintaan terhadap pekerjaan dan industrinya.

Beberapa karyawan dengan jabatan customer service dan teller mengeluh mengenai upah yang diberikan masih kurang dan beberapa karyawan merasa upah yang mereka terima sudah cukup maka dari itu peneliti mengambil kasus dengan judul faktor-faktor yang mempengaruhi motivasi kerja di BCA KCU Pangeran Jayakarta. Peneliti hanya fokus dengan satu variabel yaitu upah karena upah merupakan salah satu faktor yang dapat mempengaruhi menurunya motivasi kerja dalam penelitian ini peneliti ingin mengali kasus ini lebih dalam lagi sehingga peneliti mengunakan jenis penelitian kualitatif dengan teknik pengumpulan data observasi, wawancara dokumentasi dan angket. Agar memudahkan peneliti untuk mengali informasi yang sebenarnya terjadi dalam kasus ini.

Menurut Umar dalam Rivai (2011:406), dengan semakin ketatnya persaingan bisnis, industri harus mampu bersaing dan salah satu alat yang dapat digunakan oleh industri adalah upah. Jika sistem upah dirasakan adil dan kompetitif oleh karyawan, maka industri akan lebih mudah untuk menarik pekerja yang potensial, mempertahankannya dan memotivasi agar lebih meningkatkan kinerjanya, sehingga produktivitas meningkat dan industri mampu menghasilkan produk dengan harga yang kompetitif, yang pada akhirnya, industri bukan hanya unggul dalam persaingan, namun juga mempertahankan kelangsungan hidupnya, bahkan mampu meningkatkan profitabilitas dan mengembangkan usahanya.

Selain itu disiplin kerja juga dapat membantu karyawan untuk meningkatkan kinerjanya dan menjadi persyaratan bagi karyawan dalam hal pembentuk sikap, perilaku, dan tata berdisiplin yang akan membuat karyawan dapat kemudahan dalam bekerja. Mempunyai karyawan yang memiliki disiplin kerja yang tinggi 
akan mencipkan suasana kerja yang kondusif dan mendukung perusahan dalam mencapai. Sedangkan menurut Siagian dalam Sari (2013:2). Disiplin adalah sikap kesediaan dan kerelaan seseorang untuk mematuhi dan mentaati norma-norma peraturan yang berlaku disekitarnya.

Pemberian upah yang adil dan setimpal akan memicu motivasi kerja yang tinggi sehingga kinerja para buruh/pekerja menjadi lebih baik dan tentunya pengaruh terhadap pendapatan perusahaan. Pemberian upah berguna untuk meningkatkan output dan efesien, kita haruslah menyadari akan berbagai kesulitan yang timbul dari sistem pengupah insentif.

Menurut Hariandja dalam Sari (2013:2) insentif diartikan sebagai bentuk indentif diartikan sebagai bentuk pembayaran langsung yang didasarkan atau dikaitakan langsung dengan kinerja atau gain sharing, yang juga dikaikan dengan kinerja dan diartikan sebagai pemberi keuntungan bagi pegawai akibat peningkatan produktivitas atau penghemat biaya.

\section{Fokus Penelitian}

Rendahnya upah yang diberikan oleh pihak manajemen BCA KCU Pangeran Jayakarta mempengaruhi banyak variabelvariabel antara lain motivasi kerja, insentif dan disiplin kerja yang pada dasarnya saling berkaitan, namun dalam hal ini penulis hanya membatasi masalah tersebut antara pengaruh upah terhadap motivasi kerja berkaitan hal tersebut diatas dan atas pengamatan yang telah dilakukan maka penulis merumuskan masalah yang akan diuraikan dan dibahas yaitu mengenai bagaimana pengaruh upah terhadap motivasi kerja BCA KCU Pangeran Jayakarta.

1. Pemberian upah yang rendah oleh pihak manajemen BCA KCU Pangeran Jayakarta dan tidak sesuai dengan standart upah minimum yang telah ditetapkan untuk memenuhi kebutuhan hidup yang layak.

2. Tidak adanya kompetensi/insentif yang diterima karyawan atas tambahan jam kerja di BCA KCU Pangeran Jayakarta.

3. Motivasi kerja karyawan BCA KCU Pangeran Jayakarta yang rendah dimana dalam pelaksanaan kerja para karyawan banyak yang mengeluh, tidak bersemangat dalam bekerja, dan merasa tidak adanya keadilan dalam pengupahan.

4. Tidak terciptanya kepuasan karyawan BCA KCU Pangeran Jayakarta.

5. Kurangnnya disiplin karyawan BCA KCU Pangeran Jayakarta yang rendah terlihat ketika dalam pelaksanaan kerja tidak mengindahkan tatatertib kerja.

6. Manajamen BCA KCU Pangeran Jayakarta yang buruk 
dalam pengelolaan mekanisme pengupahan.

\section{METODE PENELITIAN}

Pendekatan yang digunakan dalam penelitian ini adalah pendekatan kualitatif. Menurut Sukmadinata (2013) mendefinisikan bahwa penelitian kualitatif adalah suatu penelitian ilmiah yang bertujuan untuk memahami suatu fenomena dalam konteks sosial secara alamiah yang dengan mengedepankan proses interaksi komunikasi yang mendalam antara peneliti dan fenomena yang diteliti.

Periset adalah bagian integral dari data, artinya periset ikut aktif dalam menentukan jenis data yang diinginkan. Dengan demikian, periset menjadi instrument riset yang harus terjun langsung di lapangan. Karena itu peneliti kualitatif bersifat subjektif dan hasilnya lebih kasuistik, bukan untuk digeneralisasikan. Desain riset dapat berubah atau disesuaikan dengan perkembangan riset.

Alasan memilih pendekatan kualitatif karena hal ini berkaitan dengan konsep judul dan rumusan masalah yang dikemukakan pada pendahuluan yang mengarah pada faktor-faktor yang mempengaruhi motivasi kerja di BCA KCU Pangeran Jayakarta, dimana faktorfaktor yang mempengaruhi ini beragam dan setiap karyawan berbeda-beda.

Lebih lanjut Muhammad dalam Emir (2013) salah satu alasan mengapa seseorang melakukan penelitian kualitatif adalah karena topik yang diteliti perlu dieksplorasi. Sementara metode ini dipilih oleh peneliti karena tujuan dari penelitian ini mengeksplorasi apa saja faktorfaktor yang mempengaruhi motivasi kerja di BCA KCU Pangeran Jayakarta.

\section{HASIL DAN PEMBAHASAN \\ Hasil Penelitian}

Data dari hasil pada penelitian ini didapatkan melalui wawancara mendalam yang dilakukan peneliti dalam kurung waktu bulan juni 2017 dimana seluruh informan yang melakukan wawancara mendalam adalah karyawan BCA KCU Pangeran Jayakarta. Berdasarkan wawancara mendalam yang dilakukan oleh peneliti terhadap informan mengenai Faktor-faktor yang mempengaruhi motivasi karyawan di BCA KCU Pangeran Jayakarta diperoleh hasil yang hampir serupa antar jawaban yang satu dengan jawaban yang lainnya dari masing-masing informan.

Seperti hasil wawancara mendalam tentang faktor-faktor yang mempengaruhi motivasi kerja di BCA KCU Pangeran Jayakarta, yang dilakukan kepada 5 orang karyawan informan. 
a. Apa perusahaan memberikan upah yang cukup memadai untuk memenuhi kebutuhan sandang pangan dan papan.

Di BCA KCU Pangeran Jayakarta terdapat beberapa karyawan yang mengeluh mengenai upah/gaji yang diterima oleh karyawan disetiap bulannya. Peneliti ingin mengetahui apakah betul perusahaan yang besar tersebut memberikan upah yang tidak sesuai kepada karyawannya.

Berdasarkan pemaparan dari hasil wawancara dengan informan, peneliti dapat mengambil kesimpulan bahwa perusahaan sudah memberikan gaji/upah yang cukup untuk memenuhi kebutuhan karyawan namun ada beberapa karyawan yang masih kurang puas dengan hasil yang diberikaan oleh perusahaan.

b. Apa perusahaan memberikan jaminan keamanan dan keselamatan kerja kepada karyawan

Perusahaan memberikan jaminan keamanan dan keselamatan kerja agar setiap pegawai mendapat jaminan keselamatan dan kesehatan kerja baik secara fisik pencahayaan yang kurang di ruangan dapat menyebabkan gangguan penglihatan dan kecelakaan kerja, sosial dan psikologis stres akibat jam kerja terlalu tinggi atau tidak sesuai waktunya.
Berdasarkan hasil wawancara dengan para informan, peneliti dapat mengambil kesimpulan bahwa jaminan keamanan dan keselamatan kerja sudah diberikan perusahaan untuk semua karyawan.

c. Bagaimana situasi tempat kerja yang nyaman dan karyawan saling menghargai sehingga hubungan antara karyawan sangat baik

Dunia kerja terkadang menghadirkan berbagai hal lain selain dari pekerjaan dan gaji yang mendukung produktifitas. Disinilah kita bisa mempertimbangkan beberapa hal yang membuat lingkungan kerja nyaman serta memberikan inspirasi dan motivasi dalam bekerja. Lingkungan kerja yang nyaman merupakan suatu tempat ataupun keadaan kehidupan sosial yang ada di sekitar tempat yang dapat mempengaruhi kinerja karyawan baik secara langsung maupun tidak langsung.

Berdasarkan paparan dari hasil wawancara, peneliti dapat mengambil kesimpulan bahwa komunikasi yang baik dan saling membatu karyawan satu dengan karyawan yang lainnya akan tercipta hubungan dan lingkungan kerja yang baik. Disamping itu juga adanya sikap saling menghargai akan menghasilkan atau menimbulkan kerjasama yang baik. 


\section{d. Apa perusahaan memberikan pujian, bonus dan reward kepada karyawan yang berpestasi}

Salah satu kewajiban perusahaan terhadap karyawan adalah memenuhi hak-haknya, yakni dengan memberikan kompensasi atau balas jasa atas pekerjaan yang telah dikerjakannya. Mengigat, karyawan memiliki peran penting di perusahaan dalam proses terlaksanya suatu pekerjaan. Bonus dan reward dapat berupa imbalan material dan non-material. Material bisa diberikan dengan carapenyesuaian gaji atau bonus-bonus terhadap karyawan yang memberikan kontribusi terbaik kepada perusahaan. Kemudian reward non-material bisa diberikan misalnya melalui pujian dan rasa simpati. Pujian secara personal atau di depan karyawan lain apabilakaryawan tersebut berhasil menyelesaikkan tugas yang memenuhi ekspediktasi perusahaan.

Setiap jawaban informan hampir memiliki jawaban yang sama seperti memacu karyawan untuk bekerja dengan baik lagi. Kesimpulan dari wawancara dengan informan, peneliti menyimpulkan apabila perusahaan memberikan pujian, bonus dan reward kepada karyawan yang berpestasi itu sangat menguntungkan bagai karyawan dan perusahaan dengan adanya pujian, bonus dan reward, diharapkan karyawan akan memotivasi dirinya untuk selalu meningkatkan kinerja.

e. Apa perusahaan memberikan kesempatan kepada karyawan untuk mengembangkan karir Perusahaan yang besar merupakan perusahaan yang berani menjamin kehidupan yang lebih baik untuk para karyawan. Perusahaan besar akan memberikan manfaat pengembangan karir karyawan dalam perusahaan bagi setiap orang.

Berdasarkan hasil wawancara dengan informan, peneliti menyimpulkan bahwa perusahaan memberikan kesempatan kepada karyawan untuk mengembangkan karir. Misalnya, karyawan menempuh pendidikan dengan kuliah malam setelah pulang kerja. Perusahaan juga memberikan jenjang karir yang pasti, sehingga setiap karyawan bisa berkembang. Dengan jenjang karir tersebut karyawan menjadi lebih bersemangat dan termotivasi bekerja untuk memperoleh hasil yang lebih baik lagi.

Peneliti tidak hanya mewawancara informan namun peneliti juga menyebarkan dua angket, pertama motivasi yang terdiri dari 5 pertanyaan dan kedua upah yang terdiri dari 5 pertanyaan. Berikut terlampir angket yang sudah dijawaban oleh masing-masing 
informan. Hasil yang sudah dijawab oleh masing-masing informan digabungkan untuk memudahkan peneliti melihat pilihan informan.

Dari angket diatas dapat disimpulkan dari hasil pilihan informan ada 2 pilihan yang tertinggi diantara perlu adanya kenaikan gaji dan gaji yang cukup diatas UMR peneliti akan menyimpulkan salah pilihan yang tertinggi informan yaitu perihal perlu adanya kenaikan gaji dari 5 informan macam pilih sangat setuju.

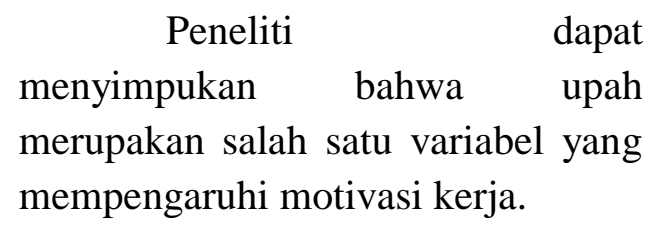

\section{Pembahasan}

\section{a. Upah}

Perdiana dalam heidjrahman dan suad husnan (2005:14-22) upah juga bisa dikatakan sebagai imbalan yang diberikan kepada tenaga kerja langsung yang hasil kerjanya dapat diukur dengan satuan tertentu (jumlah fisik barang yang dihasilkan atau masa atas jasa pekerjaan yang diserahkan). Pemberian upah kepada buruh/pekerja hendaknya berdasarkan atas asas keadilan yang artinya adil bagi buruh/pekerja atas apa yang dikerjakannya serta mampu untuk memenuhi kebutuhan hidup layak.

Besarnya upah mencerminkan nilai karya mereka diantara para buruh/pekerja atas apa yang mereka kerjakan. Oleh karena itu, bila para buruh/perkerja merasa pemberian upah yang tidak memadai/mencukupi maka produktifitas kerja, motivasi kerja, kinerja, serta kepuasan kerja mereka akan menurunkan secara drastis dimana hal ini tentunya akan berpengaruh terhadap jalannya aktifitas perusahaan.

\section{b. Motivasi}

Motivasi merupakan kondisi atau energi yang menggerakan diri karyawan yang terarah atau tertuju untuk mencapai tujuan organisasi perusahaan. Sikap mental karyawan yang pro dan positif terhadap situasi kerja itulah yang memperkuat motivasi kerjanya untuk mencapai motivasi kerja maksimal. Motivasi kerja adalah sesuatu yang menimbulkan dorongan atau semangat kerja yang dipengaruhi oleh beberapa faktor, antara lain atasan, sarana fisik, kebijaksanaan, peraturan, imbalan jasa uang dan non uang, jenis pekerjaan dan tantangan.

Motivasi menurut Munandar (2004) adalah suatu proses dimana kebutuhan-kebutuhan mendorong seseorang untuk melakukan serangkaian kegiatan yang mengarah pada tercapainya tujuan tertentu. Bila kebutuhan telah terpenuhi maka akan dicapai suatu kepuasan. Sekelompok kebutuhan yang belum terpuaskan akan menimbulkan ketegangan, sehingga perlu dilakukan serangkaian kegiatan untuk mencari pencapaian tujuan khusus yang dapat memuaskan kelompok kebutuhan tadi, agar ketegangan menjadi berkurang. 


\section{c. Faktor upah terhadap motivasi kerja karyawan}

Untuk bisa memberikan hasil perusahaan dalam pencapain profit perusahaan, maka harus ditentukan dari bagaimana setiap komponen bertingkah laku di dalam pencapain profit tersebut. Upah merupakan salah satu faktor yang sangat mempengaruhi motivasi kerja yaitu suatu dorongan atas kesediaan para buruh/perkerja untuk melakukan hal yang lebih atas apa yang dikerjakan. Motivasi kerja yang rendah sebagai akibat dari pemberian upah rendah akan terlihat ketika pelaksanaan pekerjaan tidak dilakukan dengan baik, seperti dalam Equity Theory menjelaskan bahwa setelah persepsi ketidakadilan terbentuk, karyawan akan mencoba meraih kembali keadilan dengan mengurangi jumlah distribusi mereka Perdiana dalam Adams Donovan (2005:215). Misalnya, karyawan bisa saja mulai datang terlambat ke kantor atau bahkan absen sama sekali.

\section{KESIMPULAN}

$\begin{array}{rr} & \text { Berdasarkan hasil penelitian } \\ \text { terhadap } & \text { faktor-faktor yang }\end{array}$ mempengaruhi motivasi kerja di BCA KCU Pangeran Jayakarta maka dapat di simpulkan sebagai berikut:

1. Upah yang diterima oleh karyawan sudah cukup namun ada beberapa karyawan yang masih merasa bahwa upah yang mereka terima masih kurang hanya keingin dari karyawan agar menendapatkan upah yang lebih tinggi.

2. Motivasi karyawan saat ini sudah tidak mengalami kendala.

Berdasarkan hasil penelitian yang telah dilakukan penulis mempunyai beberapa saran yaitu:

1. Bagi karyawan diharapkan dengan adanya penelitian ini dijadikan sebagai pandangan dan pengetahuan keilmuan bagi masyarakat khususnya para buruh/pekerja agar mengetahui begitu besar peran buruh/pekerja dalam perekonomian.

2. Bagi Kcu Bca Pangeran Jayakarta, supaya dapat meningkatkan motivasi kerja yang baik terhadap karyawan dengan meningkatnya motivasi tersebut dapat membangun perusahaan menjadi lebih baik.

3. Peneliti selanjutnya, untuk diadakan penelitian lanjutan dengan cakupan yang lebih luas tentang motivasi kerja.

\section{REFERENSI}

Azami, Syufi. (2015). Motivasi Kerja Pada Guru Honorer. (https://gunadarma.ac.id).

Diakses 26 Januari 2018.

Kribo. (2017). Sistem Kompensasi Insentif.

(Online), (https://duniaakuntasi.blogspot.co .id/2017/09/), diakses 13 September 2017.

Mahmudah, Umi. (2015). Analisis Sistem Akuntasi Penggajian Dan Pengupahan Karyawan Untuk 
Mendukung

Tujuan

diakses

5 Maret

2019

Pengendalian Intern (Studi

Kasus Pada PT. Eastwood

Timber Industries, Gresik).

Jurnal Administrasi Bisnis,

(Online), Vol. $24 \quad$ (1),

Muhammad, Angki Mulia. (2013.

Kesadaran Hukum Masyarakat

Kampung Mahmud Untuk

Memiliki Sertifikat Atas Nama

Hak Ulayat. Skripsi tidak diterbitkan. Bandung: Program Sarjana UPI.

Perdiana. (2005). Pengaruh Upah Terhadap Motivasi Karyawan. Kompasiana, (Online), (http:www.kompasiana.com). diakses 26 Agustus 2017.

Sari, Sinta Puspita. (2013). Pengaruh Pemberian Insentif dan Disiplin terhadap Kinerja Karyawan pada PT. KSB Indonesia Cibitung. Academia, (Online), hlm. 2

(http:www.academia.edu/643782 5), diakses 5 Maret 2017.

Sukirno, Sadono. (2016). Mikro Ekonomi Teori Pengantar. Jakarta: Raja Grafindo Persada.

Sukmadinata, Nana Syaodih. (2013).

Metode Penelitian Pendidikan, Bandung: PPS UPI dan PT Remaja Rosdakarya.

Umar, Akmal. (2011). Pengaruh Upah, Motivasi Kerja, dan Kepuasan Kerja terhadap Kinerja Pekerja pada Industri Manufaktur di Kota Makassar. Jurnal Aplikasi Manajemen, (Online), Vol 10 (2): 406-407, 